Volume and Issues Obtainable at Center for Sustainability Research and Consultancy
Journal of Business and Social Review in Emerging Economies
ISSN: 2519-089X \& ISSN (E): 2519-0326
Volume 7: Issue 2 June 2021
CSR

\title{
Impact of CEO, Director and Executive Compensation on the Firm Performance with Moderating Effect of Research \& Development
}

\author{
*Saad Ur Rehman, Khwaja Fareed University of Engineering and Information Technology \\ Rahim Yar Khan, Pakistan \\ Khalil Ur Rehman, Khwaja Fareed University of Engineering and Information Technology \\ Rahim Yar Khan, Pakistan \\ Adnan Maqbool, Khwaja Fareed University of Engineering and Information Technology \\ Rahim Yar Khan, Pakistan \\ Shahid Hussain, Khwaja Fareed University of Engineering and Information Technology \\ Rahim Yar Khan, Pakistan
}

*Corresponding author's email: saadateeq195@gmail.com

\section{ARTICLE DETAILS \\ History \\ Revised format: May 2021}

Available Online: Jun 2021

\section{Keywords}

CEO, Directors, Executive compensation, Research and Development, Firm Performance

\section{JEL Classification} MO, M1

\begin{abstract}
Purpose: The aim of this article is to investigate the relationship between the CEO, Director and executives' compensation on firm performance. Moreover research and development as moderator check the relation of $R \& D$ over firm performance and CEO, directors, executives' compensation in an emerging Pakistan market.

Design/Methodology/Approach: This research uses the GSEM approach for the problem of abnormality and homoscedastic arise the sample data collected from PSE 100 index non-financial list over the era of 2014-2019.The data collection sample from 75 non-financial firm and final sample consisted on 69 firm 6 organization exclude due to unavailability of data.

Findings: This study provide the evidence that CEOs, Director, executives' compensation have a significant relation with firm performance while, R\&D show that insignificant relation with CEO/directors and Executives compensation perhaps R\&D show significant relation with firm performance. Implications/Originality/Value: This research contributed the firm with their better remuneration to the executive; CEO and director have better financial performance. Meanwhile research and development also play pivotal role toward firm performance due to their innovative idea and technique. In future other Asian countries included in the sample set like India and also some variable like CSR, Firm age, top executive education and tenure for showing the better significant results.
\end{abstract}

(C) 2021 The authors, under a Creative Commons Attribution-

NonCommercial 4.0

Recommended citation: Rehman, S., Rehman, K., Maqbool, A. and Hussain, S. (2021). Impact of CEO, Director and Executive compensation on the firm Performance with 
moderating effect Research \& Development. Journal of Business and Social Review in Emerging Economies, 7 (2), 403-414.

\section{Introduction}

From the few years span director's remuneration and role of cooperate governance were hot topic to discuss. The crisis were occurred in 1997-98 it hit the cooperate world surprisingly the developed countries like USA Uk they adopted such policies to make better cooperate governance to overcome the issue in 2007-08 sub-prime crisis happen it will greatly affect the emerging countries or undeveloped countries because of weaker policies and poor cooperate governance but it had less effect on developed countries due to adoption impressive policies in sense of director remuneration, gender diversity, pay dispersion and executive member education (Javid \& Iqbal, 2010)(Chen et al., 2011). In Pakistan they adopted those policies to hire female director to minimize the risk of male dominance and also include independent director to board to make better governance and strong policies for firm.

(Ab Razak, 2014) stated that director remuneration is the payment received on the service of director of the firm, board or cooperation. It may be compensated salary, fee use of company property as an agreement between firm and them. Board of Director categorized into two different segment executive and non-executive director. Executive Directors is member of the board executive director responsible for specifying operating role and strategic planning also participate in day to day work while non-executive director is also consider as independent director which is part of board member they are not involved in the operating function but they participate in policy making (Talha et al., 2009).Remuneration is use as motivation to director which effect the decision and strategies which being planned and adopted by director which make great impact on company performance and profitability. It also considers as reward for director it's motivating them toward their duties and it may useful to achieve the organizational goal.

Previous studies discuss that CEO compensation and director's remuneration the relationship between the performances is mixed bag. Some studies show that there is a significant linked regarding the director remuneration and firm performance. For instance, (Aslam et al., 2019) originate that there is a significant relation between the firm performance and CEO/Director compensation strongly support the agency theory while it had not significant relationship with steward theory.

The previous literature was on firm executive remuneration and director compensation is dominated by CEO compensation because it assumes that CEO is key character for performance and their success. Therefore, grater area of existing works on directors and executives compensation focused the relationship between organization performance and CEOs. (Raithatha \& Komera, 2016)(Sheikh \& Kareem, 2015) found that CEO of firms is well knowledgeable and experienced person who utilize their abilities and skill to achieve the organization target and secure the shareholder wealth.

Regarding the Pakistan studies mostly research taken out Pay performance framework and CEOs mostly CEOs work as duality role and it greatly impact on firm performance and also there is political instability also lack of cooperate governance creditability (Javid \& Iqbal, 2010). Other studies found that Pakistan as mirrors the qualities of rising business sector the impact of financial advancement and continuously changing cooperate governance policies in member of board CEOs, Directors-independent directors and executives it also make essential include female member in that fallowing post(Ur Rehman \& Mangla, 2010).

The aim of this study to explain that CEOs, Directors-independent as well and executive compensation is significantly influenced the firm performance and also accounting measure 
return on asset, equity, sale and market value of firm by tobin q. Firstly we examine that the impact of board member compensation it includes cash base incentives and non-cash base incentives on firm financial performance over the duration of 2014-2019 this time period is selected since of the disaster occurred in 2007-08 and 2012. SECP (security commission of Pakistan) modified the criteria and come with new polices of organization to disclose the board member executive, directors and CEO compensation mentioned in detailed. Moreover current study considers compensation data of the organization for last 6 years the data taken from the PSE (Pakistan stock Exchange) Pakistan non-financial sector listed in PSE 100 index. Secondly our study focus on emerging market and Pakistan is still in growing era. Large firm in Pakistan are controlled by families ownership are more common for instance in Korea and japan and USA it different from Anglo-Saxon economies and it also create the agency problem as well(Van Essen et al., 2012). In that scenario it gives better view on remuneration and firm performance on non-financial sector in Pakistan.

Thirdly, our study consider the research and development expenses as moderator how much firm invest on R\&D expenses to improves the firm performance and how research and development interlinked to CEOs, Director and executives' compensation it also relates to tobin q, ROA, ROE, ROS whether the companies improves their position or firm performance after Research and development expenses where occurred. On other hand mostly developed countries have better performance after R\&D and strongly impact on firm financial performance (Ghaffar \& Khan, 2014). Perhaps the current study refer investigate that impact of board member remuneration and also taking control variable firm size, independent director and female director which show how gender diversity affect the firm performance it also include research and development as moderator and how it will affect firm financial performance. The approach is use is GSEM generalized structural equation model square spontaneously title for the problem of data found abnormal, homoscedastic found to rectify these issue we find correlation and regression among the sample organization. The finest of our assumption and awareness, this current research be only comprehensive study or investigation done so far discuss specially the board member and female also including R\&D among Pakistani companies by using the recent data set of firms.

Previous research(Aslam et al., 2019) were not discussed these variable research and development as moderator and other control variable female ratio, Independent director. In this desired article that Research and development taking as moderator never research before with ceo, director and executive compensation furthermore some new variable also research in this research female ratio and independent director.

The whole paper builds into several parts. Section 2 overcomes the literature review and hypothesis. Section 3 describes the research and variable. Section 4 explains research methodology. Section 5 illustrate the result and discussion section 6 present the conclusion and section 7 is finding and implication.

\section{Literature Review}

\section{CEO Compensation and Organization Performance}

Remuneration is an agreement, which is tie up with Performance of firm and employees (Shao et al., 2012) establish that remuneration contract is productively gear the firm subject among the director and investor. Another study found that that pay performance frame work relates the agency theory Perhaps CEO is compensate their performance and its positively affect the company's performance (Aslam et al., 2019). In agency theory assume the power to look after organization, it involve transaction with CEOs and give compensation plan which provide chief executive with more rewards to maximize the shareholder wealth, and minimize the moral hazard issue which arise from separation of control from ownership (Bebchuk \& Fried, 2012). This assumes that positive relation between firm performance and CEOs compensation. In South 
Africa before the implication of King III the cooperate governance and their performance not such useful or improve and also director and CEO remuneration had positive effect on the organization performance but after the implication of King III cooperate governance has been improved and also CEO and board of director there compensation have a positive impact on companies performance (Padia \& Callaghan, 2020). A series of studies found that there is a positive relation with firm performance and CEOs remuneration (Raithatha \& Komera, 2016; Sheikh \& Kareem, 2015).

In Pakistan CEOs have more powerful than the rest of board member because mostly chief executive have strong relationship with shareholders or either head of controlling families business (Kashif \& Mustafa, 2013)(Javid \& Iqbal, 2010). Other study found that there is a slightly significant relationship CEOs and organization performance (Perry \& Zenner, 2001)

H1: Significant level of organization performance is positively related to future CEO compensation.

\section{Director Remuneration and firm Performance}

According to contracting theory the most productive BOD remuneration and compensation contract would results the most peak their performance. Moreover, the organizations give the greater packages or remuneration will enhances their performance while, compare them other firm which gives the lower compensation to board of director their performance is shown decline. Instead that the directors reward generally lies of different separate payments depending on several task in the different separate department inside the companies (Ab Razak, 2014). (Ghosh \& Ayan, 2015) found that in accounting point of higher director remuneration pays a better performance towards the firm performance but from investor point of view their will be a weak relationship between them high compensation not much effect on companies performance.

(Padia \& Callaghan, 2020) found that there is a positive relation between board of director remuneration and company's financial performance in Africa. Moreover, other study (Niap \& Taylor, 2012) find that there is significant relationship between firm performance and BOD remuneration in Australia. Furthermore a study found there is a significant relationship between director remuneration and firm performance in Malaysian those organization pays more remuneration to their director have better company's performance and those how paid less compensation have shown that insignificant relation between them (Ab Razak, 2014).

(Shao et al., 2012) found that there is positive relation related board of director remuneration to Tobin Q, ROA and EPS in china while there is negatively relate to ROE. Furthermore (Fernandes, 2008) find that in Portuguese the director remuneration have an insignificant between firm performance while, this research also initiate that independent directors have positively linked within the company's performance and it also occur fewer agency problem. (Scholtz \& Smit, 2012) study found that director remuneration with performance sensitivity is better for equity base except than cash based compensation. It's also found the performance energy in organization is small range from .025 for money pay of all executive corporations in South Africa. In addition several studies investigate that there is strong linked between director and firm performance and profitability as well.

H2: Director Remuneration is positively related to firm financial performance.

\section{Executives' Compensation and Firm Performance}

According to the (Pillay, 2013) Green bury report stated that there are certain element include in Executive remuneration packages given by firm these are as fallow

1. Size of basic salary is increases

2. Compensation pays to executive including incentives 
(Bebchuk \& Fried, 2012) examined the relationship between executive compensation and firm perform it found that executive compensation positively relates to firm performance. Other study (Bruce et al., 2005) found that relationship between the executives' compensation and firm performance is significant relation between them it examined in UK. A study examine in India by (Raithatha \& Komera, 2016) found that firm performance is significantly affect the executive pay compensation. Executives of organization are playing significant role toward company's performance those companies paying the higher reward and pay compensation to executive it's positively impact the firms performance (Van Essen et al., 2012).

According to (Lee et al., 2008) found that firm performance measured by Tobin Q either ROA shown the positive relation with the executive compensation. It's further stated that the executive member with the high remuneration package is significant relation with organization performance rather those have low compensation.

H3: Executive Compensation is significant relationship with firm financial performance.

\section{Research and Development and Firm Performance}

(Wang, 2011) explained that research and development is the technical innovation and improvement it provide the competitive advantage to the business toward their competitors. Furthermore it's also stated that Millions of dollars were investing on R\&D towards the advancement and improvement of product by the organization its enhancement in the firm performance. In order to succeed more profit and also compete to other firm on technical ground companies spent more on $R \& D$ expense.

According to (Ghaffar \& Khan, 2014) found that R\&D plays a positive role to gain advantage over the current and potential competitor of companies. While, in order to take a competitive edge firms should spend more cost on research and development activities. (Akcali \& Sismanoglu, 2015) stated that those firm spending higher expenditure on research and development and developing new ideas and innovate their product its paly a significant role towards firm performance.

H4: Research and Development is significant relationship with compensation of CEO, Director and Executives.

On the other hand done (Donelson \& Resutek, 2012) have an appositive side of view that research and development have a no significant relationship with profit while, it have a positive relation with the future earnings. Other research by (Leung et al., 2015) found that R\&D have a significant with relationship with firm earning in accounting point of view but in finance there is no relation research and development between firm performance and CEOs or executive compensation.

H5: Research and Development is significant relationship with firm financial performance. 


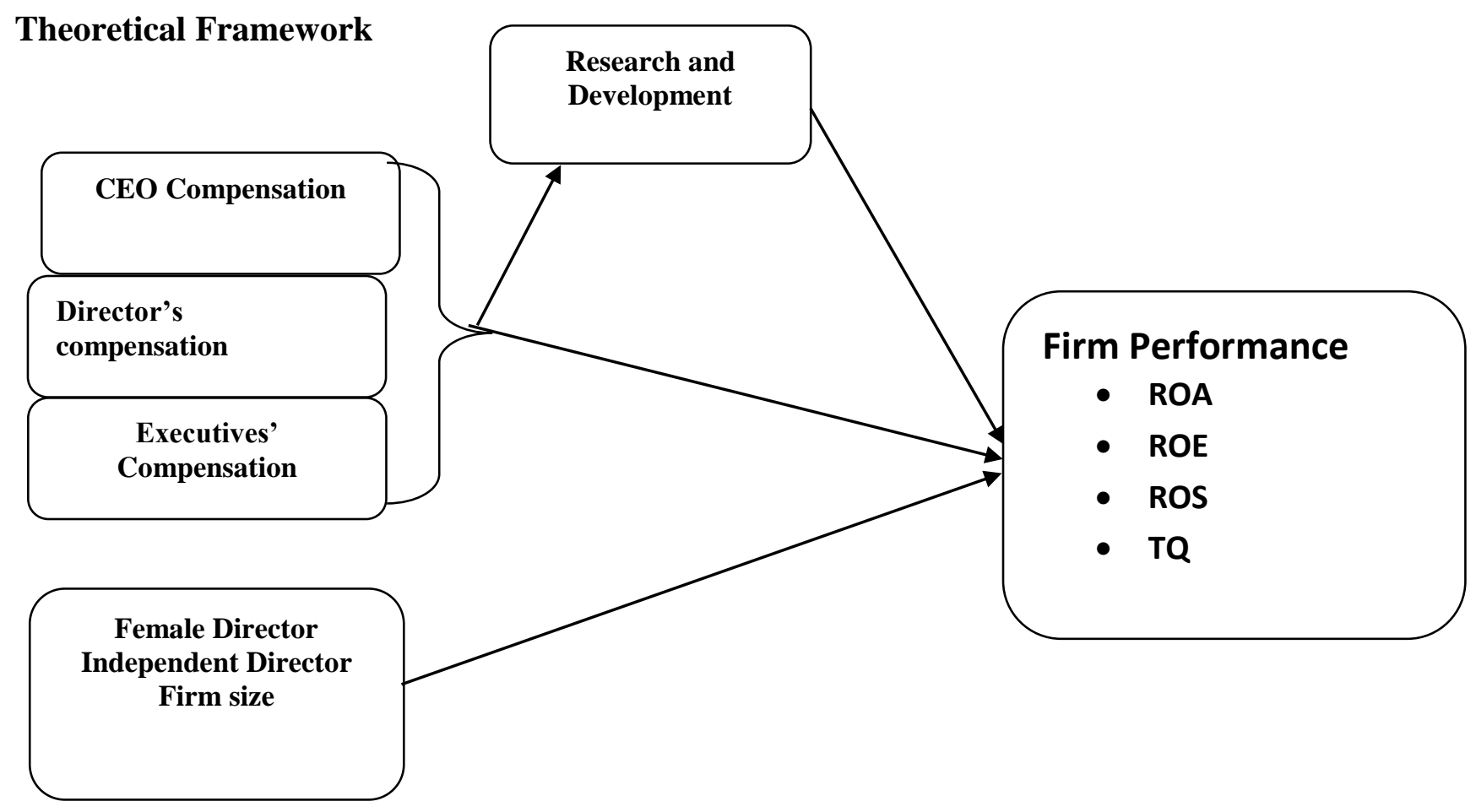

\section{Data and Variable}

\section{Data Source}

For this type of study, the data is collected from 100 index listed in Pakistan stock exchange (PSE) over the years of 2014-2019. The PSE 100 index is selected due to ordinary performance during the selective tenure in Asian market, is recognized as Asian tiger. The PSE 100 index lists mentioned the top hundred performing organization in Pakistan stock exchange (PSE).

Out of these 100 companies only non-financial sector included and 24 financial listed firms excluded (i.e. Insurance, Banking sector, leasing companies, Mudarabah and Investment companies) because they different governance structure and these organizations fallow the role regulation under the state bank of Pakistan. Furthermore, to make a better assessment this research contains a fair sample and excludes those organizations with unfinished annual statement during that tenure of research. Thus, the concluding data consist of 69 organizations with complete information about selective variable such as CEO compensation, Director Compensation, Executive compensation, Independent director, Female director, and research and development. All the sample data collected from company's annual statement physically from firm websites.

\section{Variable Selections}

Table 1 discuss the investigate variable beneath examine of entire compensation of CEOs, Directors and executive. Compensation comprised in cash base and non-cash base remuneration including all the packages that influence the organization performance (Shao et al., 2012; Sheikh \& Kareem, 2015). While, the keys research variable to examine firm performance those firm performance indicator are Tobin Q, ROA, ROE and ROS it examine the firm performance and also corporate governance variable minimize the relation regarding transparency, disclosure \& accountability (Aslam et al., 2019).

Other variable research and development as moderator significantly relate to firm performance and indicate no relation with compensation of board member. Moreover the higher the R\&D have significantly enhance the firm performance (Donelson \& Resutek, 2012). 


\section{Research Methodology}

In order check these hypotheses, the Generalized structural equation model GSEM use to investigate the relationship between the firm performance and CEO, BOD, Executives' compensation also TQ, ROA, ROE, ROS. GSEM approach control the problem of abnormality in the data and homoscedasticity. There is two main model of existing study firm performance without moderator and firm performance relates with moderator R\&D. In first Model independent variable CEO, BOD,

Table 1. Variables and Definitions

\begin{tabular}{|c|c|c|}
\hline Variables & Definition & Measure \\
\hline Tobin's Q & $\begin{array}{l}\text { The TQ ratio is a measure organization asset in relation } \\
\text { to company's market value. } \\
\text { (Aslam et al., 2019) }\end{array}$ & $\begin{array}{l}\text { The data taken from } \\
\text { financial statement it } \\
\text { measure by total market } \\
\text { capitalization }+ \text { Total debt } \\
\text { divide total asset } \\
\text { Non-accounting measure } \\
\text { (Ab Razak, 2014) }\end{array}$ \\
\hline Return on Asset & $\begin{array}{l}\text { Return on assets (ROA) its means how profitable a } \\
\text { company is relative to the total assets. ROA gives } \\
\text { investor, manager, or analyst awareness as to how } \\
\text { efficient a firm's management is at using its assets to } \\
\text { generate earnings. ROA is displayed as a percentage. } \\
\text { (Ibrahim et al., 2019) }\end{array}$ & $\begin{array}{lcr}\text { ROA is measured } & \text { as } \\
\text { operating } & \text { profit } & \text { after } \\
\text { depreciation } & & \\
\text { divided by } & \text { average } & \text { total } \\
\text { assets.(Lee } & \text { et } & \text { al., } \\
\text { 2008)(Aslam } & \text { et } & \text { al., } \\
\text { 2019)(Ab Razak, 2014) } & \end{array}$ \\
\hline
\end{tabular}

Return on Equity

Return on Sale

CEO Compensation

Director Compensation

Executive

Compensation
ROE is considered a measure of the profitability of a corporation in relation to stockholders' equity.

Return on sale determines the firm's operational efficiency. ROS. The increasing return on sale indicates the organization efficiency and decreasing ROS indicate that firm in in trouble.

.Remuneration includes the salary of, CEO, Director, Executives which includes cash based salary and noncash base reward.

(Javid \& Iqbal, 2010)
It will measure by net income divided by shareholder equity. (Aslam et al., 2019)

It will be measure by operating income/ revenue
It will be measure by taking natural $\log$ on compensation of CEO, BOD and Executives data has been taken from annual report non-financial institution (Aslam et al., 2019)

It will be measure by taking natural $\log$ of annual sale (Dalton et al., 1999) (Aslam et al., 2019)

It will be measured by taking $0,1=0$ and value more than 1 is $=1$ (Mishra \& Supriti, 2020)

If the female member is more than one we will consider one otherwise zero (Brahma et al., 2020)

It will be measure by $R \& D$ expenses divided by EBIT

(Donelson \& Resutek, 2012) 
Executive compensation is estimated with control variable and firm performance indicator. $F P i t+1=\beta 0+B 1$ ceocrit + B2direcrit + B3execrit + B4Inddit + B5Fsizeit + B6fdit + B6rdit + sit

The second equation is the research and development relation with the firm performance and the compensation of ceos, bod and executives whether the companies enhances their performance or not.

$F P i t+1=\beta 0+B 1$ ceocrit + B2direcrit + B3execrit + B4Inddit + B5Fsizeit + B6fdit + B6rdit + B6rd*ceocr + B6rd*direcr + B6rd*execr + sit

In the above two model FP represent the firm performance variable (TQ, ROA, ROE, ROS) while, $i$ denote a organization, $t$ represented a years, Perhaps ceocr, direcr, execr all are independent variable denotes the compensation packages of CEOs, board of directors, and executives. Meanwhile, set of control variable are fsize, Indd, fd (firm size, independent director, female director), Furthermore, rd including as moderator denotes research and development expenditure of firm, cit mention as the error term.

\section{Results and Discussion}

Table 3 discuss the relationship of independent variable on firm performance TQ, ROA, ROE, ROS and control variable the result shows that there is a significant relation between ceo compensation and firm performance indicator. The table shown below

Table 2. SEM - Compensation of CEO/BOD \& EXECUTIVE and also TOBIN Q, ROA, ROE, ROS as a function of firm performance.

\begin{tabular}{ccccc}
\hline Variable & Tobin Q & ROA & ROE & ROS \\
\hline & $0.057^{* *}$ & $.0103425^{* *}$ & $0.095^{* * *}$ & $0.19 *$ \\
CEOC & .0508583 & $.0104^{* *}$ & .1027 & $.0110^{* *}$ \\
DIRCR & $0.17^{* *}$ & $-.0040^{*}$ & $.0442^{* *}$ & $.0188^{* *}$ \\
EXEC & $0.076^{* *}$ & $.0050^{* *}$ & .0240 & $.0203^{*}$ \\
INDD & -.1454 & $.0057^{* *}$ & $.6783^{* *}$ & $.00626^{* *}$ \\
FD & $-.0704^{* * *}$ & $-.0319^{*}$ & $-.6964^{* *}$ & $.0097^{* *}$ \\
FSIZE & $-.1456^{*}$ & $-.0063^{*}$ & -.0076 & $-.0182^{* *}$ \\
\hline
\end{tabular}

Note: $* / * * * * *$, indicate statistical significance at $1 \%, 5 \%$ and $10 \%$ respectively.

According to the results, the relationship between CEO compensation and firm performance indicators Tobin Q, ROA, ROE, and ROS was examined. The impact of the CEO compensation on Tobin Q, ROA, ROE and ROS respectively are $(\beta=0.057, p<0.05) ;(\beta=0.10, p<0.05) ;(\beta=0.09$, $\mathrm{p}<0.10) ; \quad(\beta=0.19, \quad \mathrm{p}<0.01)$, thus, the relationship between CEO compensation and firm performance indicators were significant, so Hypothesis 1 was supported. The control variable independent director, Female director and firm size shows that there is a negative relation with the Tobin Q but it shows that there is a positive relation with ROA and ROS respectively also FD have a negative relation with director compensation.

Moreover, the combination between Board of Directors and firm performance indicators Tobin Q, ROA, ROE, and ROS was tested. The influence of the Board of Directors on Tobin Q, ROA, ROE and ROS respectively are $(\beta=0.17, p>0.05) ;(\beta=-0.004, p>0.01) ;(\beta=0.042, p>0.05)$; $(\beta=0.020, p>0.05)$, so the connection between Board of Directors and firm performance indicators were insignificant, thus, hypothesis 2 was rejected.

Furthermore, the combination between executive compensation and firm performance indicators Tobin Q, ROA, ROE, and ROS was examined. The impact of executive compensation on firm performance indicators Tobin $\mathrm{Q}, \mathrm{ROA}, \mathrm{ROE}$ and ROS respectively are $(\beta=0.076, \mathrm{P}<0.05)$; 
$(\beta=0.005, \mathrm{p}<0.05) ;(\beta=0.023, \mathrm{P}<0.05) ;(\beta=0.002, \mathrm{p}<0.05)$, so, Hypothesis 3 was supported. There is a significant relation between firm performance and executive compensation.

These result shows that firm director enhance their effort to overcome the organization target and achieved more profit when it given better compensation (Aslam et al., 2019).

Table 4 elaborates the role of moderator Research and Development on CEOs compensation, BOD and executive compensation and also on firm performance indicator TQ, ROA, ROE \& ROS. Table 4 shown below.

Table 3. GSEM - Compensation of CEO/BOD \& EXECUTIVE and also TOBIN Q, ROA, ROE, ROS as a Function of Firm Performance including Research and Development as Moderator

\begin{tabular}{|c|c|c|c|c|}
\hline Variable & Tobin Q & $\mathrm{ROA}$ & $\mathrm{ROE}$ & ROS \\
\hline & $.541 * *$ & $.06457 * *$ & $.349083 * *$ & $.0932981 * *$ \\
\hline CEOC & $.0574425 * *$ & $.0109859 *$ & $.0993063^{*}$ & $.0193949 * *$ \\
\hline DIRCR & $.0171047^{*}$ & -.0038104 & $.0429729 * *$ & $.0204156^{*}$ \\
\hline EXEC & $.0764488 * *$ & $.0057741 * * *$ & .0238098 & .0023 \\
\hline INDD & -.1613079 & .0043878 & .6865489 & .0101146 \\
\hline FD & -.068870 & $-.0318332 * *$ & -.6972721 & .0101146 \\
\hline FSIZE & $-.1450891 *$ & $-.0062747 * * *$ & $-.0079535 * * *$ & $-.0180484 * *$ \\
\hline $\mathrm{RD}$ & $15.99133 * *$ & $1.417724 * *$ & $-8.252453 * *$ & $3.885697 * * *$ \\
\hline EXECRRD & 1.347858 & -19.23106 & -19.23106 & $1.347858 * *$ \\
\hline DIRCRRD & $2.80193 *$ & $-20.80193 * *$ & -20.80193 & $2.641689 * *$ \\
\hline EXECRRD & $3.188904 * *$ & $-4.271824 *$ & -4.271824 & $3.188904 * *$ \\
\hline
\end{tabular}

Note: $* * * / * * *$, indicate statistical significance at $1 \%, 5 \%$ and $10 \%$ respectively.

The result shows that, research \& development played an insignificant moderator role between compensation of ceo, bod \& executives and firm performance indicators Tobin Q, ROA, ROE, and ROS and results are given respectively $(\beta=15.99, P>0.05) ;(\beta=1.41, p>0.05) ;(\beta=-8.25$, $\mathrm{P}>0.05) ;(\beta=3.88, \mathrm{P}>0.10)$, so $\mathrm{H} 4$ was not supported because the probability level is greater than suggested value. Moreover, research \& development showed relationship with Tobin Q, ROA, ROE and ROS respectively $(\beta=0.54, \mathrm{P}<0.05) ; \quad(\beta=0.06, \mathrm{p}<0.05) ; \quad(\beta=0.34, \mathrm{p}<0.05) ; \quad(\beta=0.09$, $\mathrm{p}<0.05)$, thus, Hypothesis 5 was supported. Furthermore R\&D plays a positive relation toward TQ, ROA and ROS but it showed they have negative relation with return on equity as well. Research and development have a positive relation with firm performance indicator it almost enhance the organization performance but they have a negative relationship with independent variable as well (Ghaffar \& Khan, 2014)

\section{Conclusion}

The research identify the relationship between the CEO, Director, Executives' compensation (including all the cash and non-cash based packages) and firm performance also and also check the effect of moderator R\&D on firm performance and ceo, bod, exec compensation. There are several proxies used market and accounting based to find relationship with organization performance. The firm performance indicator is (TQ, ROA, ROE, and ROS). The data collected from PSE100 index listed in non-financial sector over the period of 2014-2019.

The GSEM model show that there is a significant relation between compensation of ceo, directors $\&$ executives with organization performance and control variables found the positive relation between FP and independent variables as well. Several studies also strongly supported that finding the CEO, board of director and have a encouraging and significant connection with 
companies performance (Aslam et al., 2019; Javid \& Iqbal, 2010; Sheikh \& Kareem, 2015).

Perhaps the moderator shows the insignificant relationship with CEOs, BOD and executives' compensation it's also show negative relation on ceo compensation as well. While, research and development have a positive and significant relationship with companies performance (TQ, ROA, ROS) likewise, finding of (Ghaffar \& Khan, 2014) there is a significant relation with firm and R\&D.

The current research has including number of new contributor such as (Executive compensation, Female director, independent director and also research and development) existing literature and theoretical work as well. The previous studies include the interrelationship of pay performance frame work (Aslam et al., 2019) but current studies includes the executives' compensation and relation with firm performance and also other studies has not including these variables and never research before. Mostly studies not include cooperate governance variable(Chen et al., 2011; Sheikh \& Kareem, 2015) but ignoring the effect of Research and development.

\section{Findings}

The results of current research are very helpful for the regulatory authorities, policymaker and practitioner particularly for the emerging nations and corporate governance structure. The important implication of this research is the better the compensation of board and better cooperate governance policy is significantly relation with firm performance. Moreover director and ceo is the strength of firm better the compensation package it indicate the significant relation with the firm performance. For instance, in order to obtain utmost output of employees firm should take care of their board member and reform new policy to get maximum profit.

Although the current study have limited in some aspect due to shortage of time. That the studies missed some important variable CSR as moderator and also the observation is limited the sample should as collected from other Asian countries as well specially India and China it will give better and more significant result for researchers.

\section{Acknowledgement}

The author is very grateful to the supervisor intended for their very helpful suggestion to get better the excellence of research.

\section{References}

Ab Razak, N. H. (2014). Director remuneration, corporate governance and performance: A comparison between government linked companies vs non government linked companies. Corporate Board: Role, Duties and Composition, 10(2), 46-63. https://doi.org/10.22495/cbv10i2art4

Akcali, B. Y., \& Sismanoglu, E. (2015). Innovation and the Effect of Research and Development (R\&D) Expenditure on Growth in Some Developing and Developed Countries. Procedia $\begin{array}{llll}\text { Social and Behavioral } & \text { 768-775. }\end{array}$ https://doi.org/10.1016/j.sbspro.2015.06.474

Aslam, E., Haron, R., \& Tahir, M. N. (2019). How director remuneration impacts firm performance: An empirical analysis of executive director remuneration in Pakistan. Borsa Istanbul Review, 19(2), 186-196. https://doi.org/10.1016/j.bir.2019.01.003

Bebchuk, L. A., \& Fried, J. M. (2012). Executive compensation as an agency problem. The Economic Nature of the Firm: A Reader, Third Edition, 17(3), 327-345. https://doi.org/10.1017/CBO9780511817410.026

Brahma, S., Nwafor, C., \& Boateng, A. (2020). Board gender diversity and firm performance: The UK evidence. International Journal of Finance and Economics, November 2019, 1- 
16. https://doi.org/10.1002/ijfe.2089

Bruce, A., Buck, T., \& Main, B. G. M. (2005). Top executive remuneration: A view from Europe. Journal of Management Studies, 42(7), 1493-1506. https://doi.org/10.1111/j.1467-6486.2005.00553.x

Chen, J., Ezzamel, M., \& Cai, Z. (2011). Managerial power theory, tournament theory, and executive pay in China. Journal of Corporate Finance, 17(4), 1176-1199. https://doi.org/10.1016/j.jcorpfin.2011.04.008

Dalton, D. R., Daily, C. M., Johnson, J. L., \& Ellstrand, A. E. (1999). Number of directors and financial performance: A meta-analysis. Academy of Management Journal, 42(6), 674686. https://doi.org/10.2307/256988

Donelson, D. C., \& Resutek, R. J. (2012). The effect of R\&D on future returns and earnings forecasts. Review of Accounting Studies, 17(4), 848-876. https://doi.org/10.1007/s11142011-9179-y

Fernandes, N. (2008). EC: Board compensation and firm performance: The role of "independent" board members. Journal of Multinational Financial Management, 18(1), 30-44. https://doi.org/10.1016/j.mulfin.2007.02.003

Ghaffar, A., \& Khan, W. A. (2014). Impact of Research and Development on Firm Performance. International Journal of Accounting and Financial Reporting, 4(1), 357. https://doi.org/10.5296/ijafr.v4i1.6087

Ghosh, \& Ayan, R. A. (2015). Director's remuneration and correlation on firm's performance: A study from the Indian corporate. International Journal of Law and Management, Vol. $57(1), 1-29$.

Ibrahim, N. A., Md Zin, N. N., Md. Kassim, A. A., \& Tamsir, F. (2019). How Does Directors' Remuneration and Board Structure Impact on Firm Performance in Malaysia Telecommunication Industry? European Journal of Business and Management Research, 4(4), 1-7. https://doi.org/10.24018/ejbmr.2019.4.4.96

Javid, A. Y., \& Iqbal, R. (2010). Corporate governance in Pakistan: Corporate valuation, ownership and financing. PIDE Working Papers, 57, 1-87.

Kashif, S., \& Mustafa, K. (2013). The Determinants of CEO Compensation: Evidence from Family- Owned Listed Corporations in Karachi Stock Exchange. Advances in Applied Economics and Finance, 4(2), 690-699.

Lee, K. W., Lev, B., \& Yeo, G. H. H. (2008). Executive pay dispersion, corporate governance, and firm performance. Review of Quantitative Finance and Accounting, 30(3), 315-338. https://doi.org/10.1007/s11156-007-0053-8

Leung, W. S., Mazouz, K., \& Evans, K. P. (2015). A Risk Explanation for the R\&D Anomaly. Working Paper, 44(March).

Mishra, \& Supriti. (2020). Do Independent Directors Improve Firm Performance? Evidence from India. Global Business Review, 1. https://doi.org/10.1177/0972150920917310

Niap, D. T. F., \& Taylor, D. (2012). CEO Personal Reputation: does it Affect Remuneration During Times of Economic Turbulence? Procedia Economics and Finance, 2(AF), 125134. https://doi.org/10.1016/s2212-5671(12)00072-x

Padia, N., \& Callaghan, C. W. (2020). Executive director remuneration and company performance: panel evidence from South Africa for the years following King III. Personnel Review. https://doi.org/10.1108/PR-08-2019-0429

Perry, T., \& Zenner, M. (2001). Pay for performance? Government regulation and the structure of compensation contracts. Journal of Financial Economics, 62(3), 453-488. https://doi.org/10.1016/S0304-405X(01)00083-6

Pillay, R. G. (2013). Greenbury Report (UK). In Encyclopedia of Corporate Social Responsibility (pp. 1303-1308). https://doi.org/10.1007/978-3-642-28036-8_320

Raithatha, M., \& Komera, S. (2016). Executive compensation and firm performance: Evidence from Indian firms. IIMB Management Review, 28(3), 160-169. https://doi.org/10.1016/j.iimb.2016.07.002 
Scholtz, H. E., \& Smit, A. (2012). Executive remuneration and company performance for South African companies listed on the Alternative Exchange (AltX). Southern African Business Review, 16(1), 22-38.

Shao, R., Chen, C., \& Mao, X. (2012). Profits and losses from changes in fair value, executive cash compensation and managerial power: Evidence from A-share listed companies in China. China Journal of Accounting Research, 5(4), 269-292. https://doi.org/10.1016/j.cjar.2012.11.002

Sheikh, N. A., \& Kareem, S. (2015). The Impact of Board Structure , Ownership Concentration , and CEO Remuneration on Performance of Islamic Commercial Banks in Pakistan. Pakistan Journal of Islamic Research, 15, 49-59.

Talha, M., Sallehhuddin, Masuod, A., \& Shukor, M. (2009). Corporate governance and directors' remuneration in selected ASEAN countries. Journal of Applied Business Research, 25(2), 31-40. https://doi.org/10.19030/jabr.v25i2.1034

Ur Rehman, R., \& Mangla, I. U. (2010). Corporate governance and performance of financial institutions in Pakistan: A comparison between conventional and Islamic banks in Pakistan. Pakistan Development Review, 49(4), 461-475. https://doi.org/10.30541/v49i4iipp.461-475

Van Essen, M., Heugens, P. P. M. A. R., Otten, J., \& Van Oosterhout, J. (2012). An institutionbased view of executive compensation: A multilevel meta-analytic test. Journal of International Business Studies, 43(4), 396-423. https://doi.org/10.1057/jibs.2012.6

Wang, C. H. (2011). Clarifying the effects of R\&D on performance: Evidence from the high technology industries. Asia Pacific Management Review, 16(1), 51-64. https://doi.org/10.6126/APMR.2011.16.1.04 